\title{
Recycling of organic residues in compost to improve coastal sandy soil properties and cabbage shoot yield in Benin
}

\author{
Guillaume Lucien AMADJI ${ }^{1 *}$, Aliou SAIDOU ${ }^{2}$ and Latifatou CHITOU ${ }^{3}$ \\ ${ }^{1}$ Department of Crop Science, Laboratory of Soil Science, Faculty of Agronomic Science, \\ University of Abomey-calavi. BP 499 Abomey-Calavi, Republic of Benin. \\ ${ }^{2}$ Department of Crop Science, Faculty of Agronomic Sciences, University of Abomey-Calavi, \\ 01 BP 526 RP Cotonou Benin. \\ ${ }^{3}$ Research assistant, Department of Crop Science, Laboratory of Soil Science, Faculty of \\ Agronomic Sciences, University of Abomey-Calavi, BP 499 Abomey-calavi Benin. \\ *Corresponding author, Tel. (+229) 93438326, E-mail: gamadji@yahoo.fr
}

\begin{abstract}
Recycling of municipal organic waste in compost is a potential approach to addressing waste disposal problems and soil fertility management. We studied during two years experiment whether composts of municipal organic waste improved with chicken dejection $(\mathrm{MOW}+\mathrm{Cdj})$, municipal organic waste improved with cottonseeds and chicken dejection $(\mathrm{MOW}+\mathrm{Cdj}+\mathrm{Csd})$, and maize stover residues improved with chicken dejection (MSR+Cdj) may be an alternative to chemical fertilizer to improve infertile littoral sandy soil and cabbage shoot yield. $20 \mathrm{t} \mathrm{ha}^{-1}$ of each type of compost were applied according to a completely randomized bloc design with five replications. The $\mathrm{C}: \mathrm{N}$ ratio of the composts ranged between 10.5 and 12.1 quite favourable for microbiological processes in the soil. The addition of cottonseeds to the compost has improved its physical and chemical properties. Soil available phosphorus, CEC and exchangeable cations were significantly $(\mathrm{P}<0.05)$ improved according to the following order: $(\mathrm{MOW}+\mathrm{Cdj}+\mathrm{Csd})>(\mathrm{MSR}+\mathrm{Cdj})>(\mathrm{MOW}+\mathrm{Cdj})>$ Control. $6.42 \mathrm{t}$ $\mathrm{ha}^{-1}$ and $7.63 \mathrm{t} / \mathrm{ha}$ of cabbage shoot yield were obtained in 2002 and 2003 respectively with the compost MOW $+C d j+C s d$ which is significantly higher $(\mathrm{P}<0.05)$ than yields obtained with treatments MOW+Cdj and MSR $+\mathrm{Cdj}$. The use of this compost is an effective way of improving coastal sandy soil productivity.

(C) 2009 International Formulae Group. All rights reserved.
\end{abstract}

Keywords: Compost quality, soil properties, sandy soil, cabbage shoots, Benin.

\section{INTRODUCTION}

The coastal sandy soils of the garden site in Cotonou are poor in mineral and organic colloids therefore, they have low fertility level, low water retention and a shortage of macro and micronutrients (Assogba, 2001). Due to their sandy texture, instead of mineral fertilizer whose nutrients (especially $\mathrm{N}$ and $\mathrm{K}$ ) may easily be lost through leaching during watering (Nissen and Wander, 2003), a good agricultural practice involves frequent applications of organic fertilizers such as manure, plant residues or different kinds of compost (Weber et al.,
2007). In fact, the use of composts produced from municipal organic wastes not only improves the properties of the soil, but it is also an environmentally and economically sound alternative since it provides a locally available source of nutrients and reduces the risks of pollution and costs of disposal of large quantities of different refuses (Crichton et al., 2000; Laos et al., 2000; Douglas et al., 2003; Kowaljow and Mazzarino, 2007; Weber et al., 2007). These contain a substantial organic fraction (Weber et al., 2007). They improve soil structure and its capacity to store water and nutrients and 
sustain microbial activity and growth (Kowaljow and Mazzarino, 2007). Humification processes occurring during composting lead to the development of a product which is similar in appearance to soil humus (Chaves et al., 2007; Weber et al., 2007). This may serve as a valuable supply of organic material that improves soil fertility.

Nevertheless, in several cases, the addition of composts produced from municipal organic wastes caused an increase of heavy metal concentrations in soil (Illera et al., 2000; Drozd, 2003). Thus, the beneficial aspects should be assessed together with the potentially detrimental ones. In particular, sandy soils with little capacity to buffer $\mathrm{pH}$ and adsorb metals are considered as poor candidates for metal-contaminated waste application (McBride, 2003). Changes that take place in the soil environment after amendment by municipal solid waste composts have to be well recognized, since knowledge of all aspects of compost application is essential to sustainable agricultural practice.

Mostly, municipal organic waste compost has low nutrient concentrations (Chaves et al., 2007; Tognetti et al., 2008) and possess a nitrogen immobilization potential (De Neve et al., 2004; Chaves et al., 2005). It is important to design strategies by adding nitrogen-rich matter to improve the quality of the compost when it is used in the garden sandy soils. However, the efficacy of chicken manure and cottonseeds in soil improvement was proved from several studies (Mallouhi and Bioyara, 1997; Brock, 1999). These organic materials are known to be nitrogen improver but they are used in non efficient and non profitable manner by gardeners as they are spread directly on the plot without composting and sometime, without burying (Brock, 1999; Amadji, 2001). Such practice may be source of soil and water pollution as the groundwater in Cotonou is about $1 \mathrm{~m}$ from the soil surface. Adding these organic materials in the municipal organic waste to be composted, would be a sustainable way to recycle them as they improve substantially the quality of the compost.

The study aims to assess: (1) the quality of the mature municipal organic waste composts enriched with different sources nitrogen-rich materials, and (2) the comparative effectiveness of the organic waste composts in improving coastal sandy soil chemical properties and cabbage shoot yield.

\section{MATERIALS AND METHODS \\ Study area}

The experiment was carried out on the vegetable gardens site of Cotonou near the Tri postal $6^{\circ} 21^{\prime} 5.4^{\prime}$ ' north latitude and $2^{\circ} 23^{\prime}$ $10.5^{\prime}$ ' east longitude (Figure 1) and has an elevation of $5.5 \mathrm{~m}$ above the sea level for two years commencing from 2002. The climate of the region is sudano-guinean type with two rainy seasons (from late March until early July and from late September until November) and two dry seasons (from December until early March and from late July until early September). The average rainfall during the period of experiment (June to September 2002 and 2003) was $552.3 \mathrm{~mm}$; the average temperature was $26.6^{\circ} \mathrm{C}$.

The original soils of the site are as sandy as a beach from quaternary sea deposits (lithosols according to USDA textural classes) and very poor in nutrient. Soil chemical properties $(0-15 \mathrm{~cm}$ depth $)$ are: $\mathrm{pH}_{\mathrm{H} 2 \mathrm{O}}$ and $\mathrm{pH}_{\mathrm{KCl}} 7.24$ and 7.21 respectively; cation exchange capacity (CEC) $1.8 \mathrm{cmol} \mathrm{kg}^{-1}$, with $0.95, \quad 0.14$ and $0.47 \mathrm{cmol} \mathrm{\textrm {kg } ^ { - 1 }}$ being contributed by $\mathrm{Ca}^{2+}, \mathrm{Mg}^{2+}$ and $\mathrm{K}^{+}$ respectively; available $\mathrm{P}$ (Bray 1) and total-P 16.6 and $134.9 \mathrm{mg} . \mathrm{kg}^{-1}$ respectively ; organic$\mathrm{C}$ and total-N $1.14 \%$ and $0.07 \%$ respectively.

\section{Experimental design}

The compost consisted of $400 \mathrm{~kg}$ of a mixture of : municipal organic wastes enriched with chicken dejection $(\mathrm{MOW}+\mathrm{Cdj})$ at waste:dejection $=5: 1$ ratio $(333.3 \mathrm{~kg}$ of waste $+66.7 \mathrm{~kg}$ of dejection); municipal organic wastes enriched with chicken dejection and cottonseeds $(\mathrm{MOW}+\mathrm{Cdj}+\mathrm{Csd})$ at waste:cottonseeds: dejection $=2.5: 2.5: 1$ ratio $(166.7 \mathrm{~kg}$ of waste $+166.7 \mathrm{~kg}$ of cottonseeds $+66.7 \mathrm{~kg}$ of dejection) and maize stover residues enriched with chicken dejection $(\mathrm{MSR}+\mathrm{Cdj})$ at stover residue: dejection $=5: 1$ ratio $(333.3 \mathrm{~kg}$ of waste: $66.7 \mathrm{~kg}$ of dejection). An absolute control plot where no nutrient sources were applied was included for treatment comparison. The selection of these different compost treatments was motivated by the 


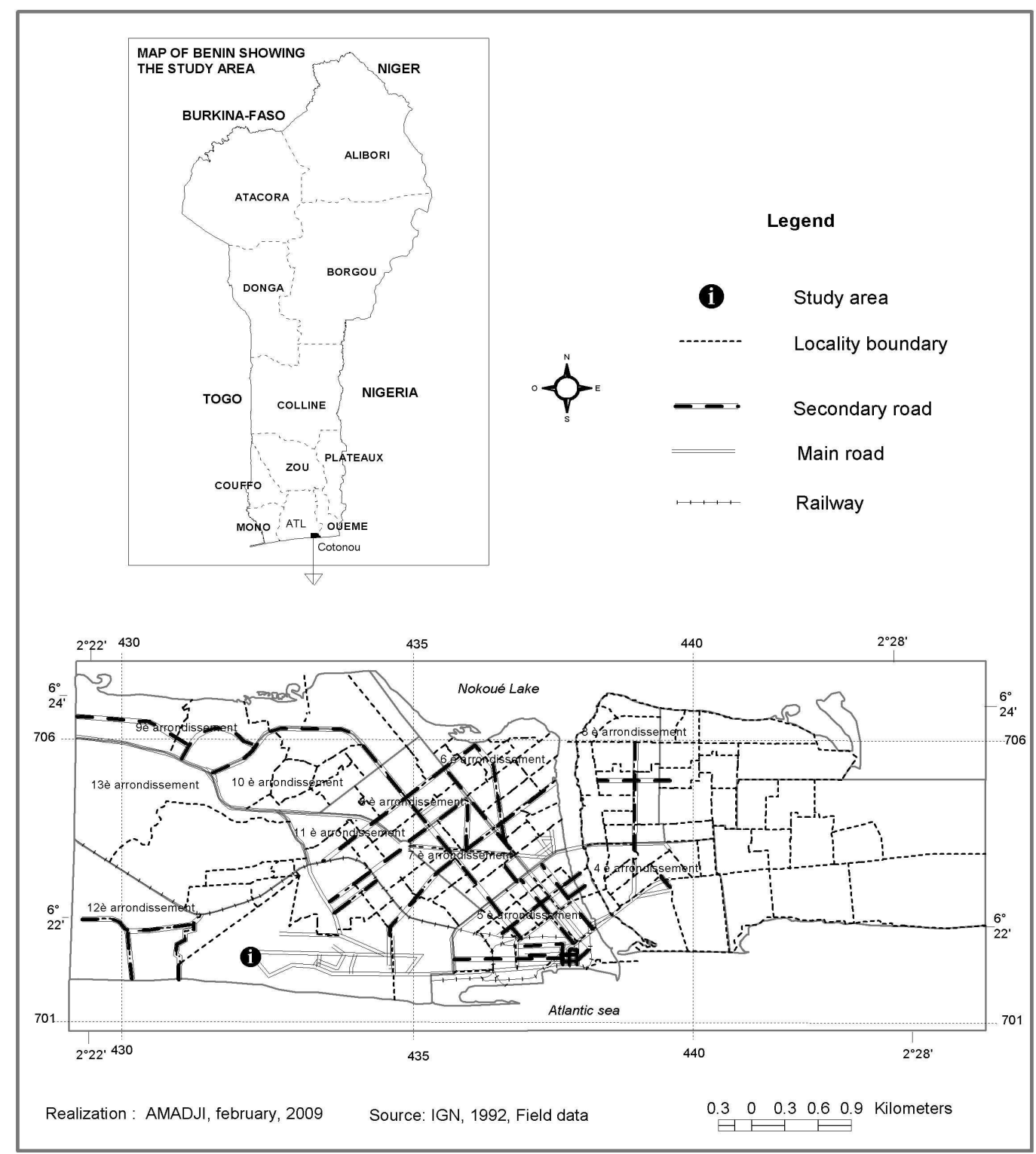

Figure 1: Map of Cotonou, Benin, indicating the studied site.

outcome of research carried out by Cédric (1996) and Amadji (2001). These authors obtained low carrot and amaranth yields when low amount of N-rich material was used to enrich the municipal organic wastes. They suggested to diversify the source of N-rich organic material and to increase the quantity used to enrich the municipal organic waste during the composting process. Maize stover residues were included for comparison purpose with the organic municipal wastes. The maize stover residues were collected from neighbouring fields located at Hevié, the municipal organic wastes from Cotonou's rubbish tip, chicken dejection from breeding farm located at Sékou (30 km from Cotonou) and cottonseeds from vegetable oil factory located at Bohicon (120 km from Cotonou). The municipal organic wastes consisted of leaves, woods, herbs and food leftovers. Any metallic objects, battery and plastic were removed from the pile of the organic material to be composted. These piles of organic material were constituted of alternate layers 
of: municipal organic waste + chicken dejection (for $\mathrm{MOW}+\mathrm{Cdj}$ treatment), municipal organic waste + chicken dejection + cottonseeds (for $\mathrm{MOW}+\mathrm{Cdj}+\mathrm{Csd}$ ) and maize stover residues + chicken dejection (for $\mathrm{MSR}+\mathrm{Cdj}$ ) according to the different ratio. All of these constituents were mixed up during the first turning over. Altogether, four treatments combinations were laid out under completely randomized block design with five replications. The total land area for the experiment was $170.5 \mathrm{~m}^{2}$ (15.5 m x $11 \mathrm{~m}$ with $1 \mathrm{~m}$ path between replication and $0.5 \mathrm{~m}$ path between elementary plots) and the elementary plot size was $3 \mathrm{~m}^{2}$ (3 $\left.\mathrm{m} \times 1 \mathrm{~m}\right)$. An amount of $20 \mathrm{t} \mathrm{DM} \mathrm{ha}^{-1}$ of compost was applied broad cost on the soil as organic sources of nutrients, which consisted of $6 \mathrm{~kg}$ DM of matured compost per elementary plot when preparing the seed bed. Land preparation consisted of ploughing, removing the herbs, levelling and pilling the sand in order to make a bed for the plant.

The variety of cabbage (Brassica oleracea L.) hydride K.K. cross from Holland, with cropping cycle of 90 days was planted at density of 62,500 plants ha ${ }^{-1}$ (24 plants per elementary plot). Plots were kept weed-free throughout the cropping cycles. As the cabbage knows less attack by the pests in the area, mostly the gardeners do not apply pesticide. Therefore, as the local cropping practice, no pesticide was used in the course of this experiment.

\section{Chemical analysis of the composts and the soils}

The soils were sampled in each elementary plot at the harvest period from five cores with a post-hole auger according to two diagonals crossed at the depth of $0-20 \mathrm{~cm}$, mixed, dried and sieved at $2 \mathrm{~mm}$ of mesh for the analyses in the laboratory. The analyses were performed in the laboratory of Soil Sciences of the Faculté des Sciences Agronomiques of the University of Abomey Calavi in Benin. Analyses included particle size distribution (by sieve and pipette method after removal of organic matter, carbonates and iron oxides), $\mathrm{pH}_{\mathrm{H} 2 \mathrm{O}}$ and $\mathrm{pH}_{\mathrm{KCl}}$ (using glass electrode in 1:2.5 v/v soil solution), total $\mathrm{N}$ (Kjeldahl method, digestion in a mixture of $\mathrm{H}_{2} \mathrm{SO}_{4}$-selenium followed by distillation and titration), exchangeable cations (with $1 \mathrm{~N}$ ammonium acetate at $\mathrm{pH} 7$, then $\mathrm{Ca}^{2+}$ and $\mathrm{Mg}^{2+}$ were determined by Atomic Absorption Spectrophotometry and $\mathrm{K}^{+}$was determined by flame photometer), CEC (1 $\mathrm{N}$ ammonium acetate at $\mathrm{pH} 7$, desaturation of clay-humus complex and determination of desorbed ammonia by micro-Kjeldahl distillation), organic carbon (Walkley-Black, 1934, wet oxidation with $\mathrm{K}_{2} \mathrm{Cr}_{2} \mathrm{O}_{7}$ procedure), available phosphorus (Bray-1 method) and total phosphorus after calcinations (Dabin ,1967).

A quantity of $400 \mathrm{~g}$ of the matured composts were sampled after sieving i.e. after three months of composting process and sent to the laboratory, where they were dried at 60 ${ }^{\circ} \mathrm{C}$ in an electric oven until constant weight and stored for chemical analyses. The analyses included organic matter content (by incineration at $450{ }^{\circ} \mathrm{C}$ ); total nitrogen (microKjeldahl distillation in a mixture of $\mathrm{H}_{2} \mathrm{SO}_{4}$ selenium followed by distillation and titration); $\mathrm{pH}-\mathrm{H}_{2} \mathrm{O}$ and $\mathrm{pH}-\mathrm{KCl}$ (using glass electrode in $1: 2.5 \mathrm{v} / \mathrm{v}$ soil solution); total phosphorus (after calcinations) total potassium (after calcinations and $\mathrm{K}^{+}$in the ash by flame photometer); bulk density (determination of the fresh weight of a known volume of compost, this was done in the field after sieving the compost), water holding capacity (oven dry method) (Page et al., 1982)

\section{Assessment of the compost yield}

The compost yield was calculated as follows: Compost yield $(\%)=$

$$
\frac{\text { Weight..of..the..mature..compost }}{\text { Weight..of..the..initial..raw..material }} \times 100
$$

\section{Cabbage yield}

During the harvest, in order to avoid the border effect, only the central line was harvested (leaving the two border rows and plants alongside), leading to harvested area of $1.04 \mathrm{~m}^{2}$. The fresh shoots of cabbage were separated from the stems and weighed in the field with scales $( \pm 0.05 \mathrm{~kg}$ sensibility).

\section{Statistical analysis}

Statistical analyses were performed using the SAS package. The parameters were subjected to a one way analysis of variance. The Student Newman-Keuls test was performed to compare differences in means among treatments. All significance levels were set at $\mathrm{P}<0.05$. 


\section{RESULTS}

Characteristics of the composts

Compost $(\mathrm{MOW}+\mathrm{Cdj})$ and $(\mathrm{MOW}+\mathrm{Cdj}+\mathrm{Csd})$ have $\mathrm{pH}_{\mathrm{H} 2 \mathrm{O}}$ fairly neutral while $(\mathrm{MSR}+\mathrm{Cdj})$ is alkaline in reaction (Table 1). Compost $(\mathrm{MOW}+\mathrm{Cdj}+\mathrm{Csd})$ enriched with cottonseeds showed almost the highest chemical (Table 1) and physical (Table 2) properties. Organic-C content was 1.6 and 1.4 time significantly $(\mathrm{P}<0.01)$ higher than composts $(\mathrm{MOW}+\mathrm{Cdj})$ and $(\mathrm{MSR}+\mathrm{Cdj})$ respectively, total-N was almost 1.8 time significantly $(\mathrm{P}<0.01)$ higher than both composts (MOW+Cdj) and $(\mathrm{MSR}+\mathrm{Cdj})$, total-K was 2.2 and 1.4 times significantly $\quad(\mathrm{P}<0.01) \quad$ higher than $(\mathrm{MOW}+\mathrm{Cdj})$ and $(\mathrm{MSR}+\mathrm{Cdj})$ respectively. However, the total-P contents are almost similar in the two types of compost produced with cottonseeds and maize stover residue, but 1.4 time significantly $(\mathrm{P}<0.05)$ higher than compost $(\mathrm{MOW}+\mathrm{Cdj})$.
From the results of Table 2 it also appears that, compost (MOW+Cdj+Csd) shows higher yield and water holding capacity. Its yield is 1.6 time significantly $(\mathrm{P}<0.05)$ higher than compost $(\mathrm{MSR}+\mathrm{Cdj})$ and similar with the yield of compost $(\mathrm{MOW}+\mathrm{Cdj})$ while water holding capacity was 1.9 and 1.4 significantly $(\mathrm{P}<0.01)$ higher than composts $(\mathrm{MOW}+\mathrm{Cdj})$ and $(\mathrm{MSR}+\mathrm{Cdj})$ respectively. However, the bulk densities of composts $(\mathrm{MOW}+\mathrm{Cdj}+\mathrm{Csd})$ and $(\mathrm{MSR}+\mathrm{Cdj})$ are almost similar but that of compost $(\mathrm{MOW}+\mathrm{Cdj})$ is almost 1.3 time significantly $(\mathrm{P}<0.0001)$ higher than that of compost (MOW+Cdj+Csd).

Based on these characteristics, these composts could be an alternative source of nutrient for the improvement of the physical and chemical properties of the infertile coastal sandy soil, as they could contribute in an efficient way in the building up of soil organic matter.

Table 1: Chemical properties (mean values \pm standard errors) of the mature composts as influenced by different $\mathrm{N}$-source materials.

\begin{tabular}{lccccc}
\hline \multirow{2}{*}{ Types of compost } & \multirow{2}{*}{$\mathbf{p H}-\mathbf{H}_{2} \mathbf{O}$} & \multicolumn{4}{c}{ Chemical properties $\left(\mathbf{m g ~ K g}^{\mathbf{- 1}}\right)$} \\
\cline { 3 - 6 } & & Organic-C & Total-N & Total-P & Total-K \\
\hline (MOW+Cdj) & $7.47 \pm 0.09$ & $150.6 \pm 9.2 \mathrm{~b}$ & $13.13 \pm 1.48 \mathrm{~b}$ & $4.14 \pm 0.19 \mathrm{~b}$ & $7.0 \pm 0.7 \mathrm{c}$ \\
(MOW +Cdj+Csd) & $7.71 \pm 0.17$ & $248.2 \pm 19.7 \mathrm{a}$ & $23.73 \pm 1.09 \mathrm{a}$ & $5.65 \pm 0.94 \mathrm{a}$ & $15.1 \pm 1.7 \mathrm{a}$ \\
$(\mathbf{M S R}+\mathbf{C d j})$ & $8.08 \pm 0.28$ & $173.1 \pm 23.6 \mathrm{~b}$ & $14.3 \pm 1.67 \mathrm{~b}$ & $5.42 \pm 0.31 \mathrm{a}$ & $10.8 \pm 2.1 \mathrm{~b}$ \\
$\mathbf{C V}(\boldsymbol{\%})$ & 3.52 & 12.31 & 19.32 & 12.17 & 18.50 \\
\hline
\end{tabular}

Note: $(\mathrm{MOW}+\mathrm{Cdj})=$ Municipal organic wastes mixed with chicken dejection; $(\mathrm{MOW}+\mathrm{Cdj}+\mathrm{Csd})=$ Municipal organic wastes mixed with chicken dejection and cottonseeds; $(\mathrm{MSR}+\mathrm{Cdj})=$ Maize stover residues mixed with Chicken dejection. Means within each column followed by the same letter are not significantly different $(\mathrm{P}>0.05)$ according to Student Newman-Keuls test.

Table 2: Physical properties (mean values \pm standard errors) of the mature composts as influenced by different $\mathrm{N}$-source materials.

\begin{tabular}{lccc}
\hline & \multicolumn{3}{c}{ Physical properties } \\
\cline { 2 - 4 } Types of compost & $\begin{array}{c}\text { Bulk density } \\
\left(\mathbf{g ~ c m} \mathbf{~ c m}^{-3}\right)\end{array}$ & $\begin{array}{c}\text { Yield } \\
(\boldsymbol{\%})\end{array}$ & $\begin{array}{c}\text { Water holding capacity } \\
(\boldsymbol{\%})\end{array}$ \\
MOW + Cdj & $0.843 \pm 0.009 \mathrm{a}$ & $45.33 \pm 2.72 \mathrm{a}$ & $68.63 \pm 2.80 \mathrm{c}$ \\
MOW + Cdj+Csd & $0.693 \pm 0.22 \mathrm{~b}$ & $50.67 \pm 2.67 \mathrm{a}$ & $133 \pm 7.19 \mathrm{a}$ \\
MSR+Cdj & $0.751 \pm 0.062 \mathrm{ab}$ & $30.90 \pm 2.68 \mathrm{~b}$ & $94.90 \pm 5.8 \mathrm{~b}$ \\
CV $(\%)$ & 4.94 & 9.95 & 20.32 \\
\hline
\end{tabular}

Note: $(M O W+C d j)=$ Municipal organic wastes mixed with chicken dejection; $(M O W+C d j+C s d)=$ Municipal organic wastes mixed with chicken dejection and cottonseeds; $(\mathrm{MSR}+\mathrm{Cdj})=$ Maize stover residues mixed with Chicken dejection. Means within each column followed by the same letter are not significantly different $(\mathrm{P}>0.05)$ according to Student Newman-Keuls test 
Effect of the different types of compost on soil chemical properties

Soil chemical properties after harvesting cabbage as influenced by the different nutrient sources in 2002 and 2003 were presented in Tables 3 and 4. From these tables it appears that, from 2002 to 2003 soil chemical properties remain almost similar. Soil $\mathrm{pH}_{\mathrm{H} 2 \mathrm{O}}$ and $\mathrm{pH}_{\mathrm{KCl}}$ were slightly neutral and $\mathrm{pH}_{\mathrm{KCl}}$ are similar regarding the different treatments but $\mathrm{pH}_{\mathrm{H} 2 \mathrm{O}}$ of the plots where the compost (MSR+Cdj) was applied were significantly $(\mathrm{P}<0.05)$ higher than that of the control. As the results of the compost quality, from 2002 to 2003 compost mixed with cottonseeds (MOW+Cdj+Csd) shows almost the highest soil chemical properties. However, soil organic carbon and total nitrogen content in 2002 are quite similar even with the control plot. Nevertheless, in 2003 a significant $(\mathrm{P}<$ $0.05)$ decrease of soil organic carbon was registered in the control plot compared with the plots where the composts were applied whereas, nitrogen content remain similar with the control plot.

The supply of composts $(\mathrm{MOW}+\mathrm{Cdj})$, $(\mathrm{MOW}+\mathrm{Cdj}+\mathrm{Csd})$ and $(\mathrm{MSR}+\mathrm{Cdj})$ has 1.4 , 3.6 and 2.7 times significantly $(\mathrm{P}<0.0001)$ improved soil total $\mathrm{P}$ content respectively compared with the control plot in 2002 and 2003. Furthermore, significant differences in soil total-P are also noticed between the treatments. A significant $(\mathrm{P}<0.0001)$ increase of soil available $\mathrm{P}$ of 1.4 to 1.7 compared with the control were noticed with compost $(\mathrm{MOW}+\mathrm{Cdj}+\mathrm{Csd})$ in 2002 and 2003 respectively, whereas composts $(\mathrm{MOW}+\mathrm{Cdj})$ and (MSR+Cdj) shows similar effect.

The supply of composts $(\mathrm{MOW}+\mathrm{Cdj}+\mathrm{Csd})$ and $(\mathrm{MSR}+\mathrm{Cdj})$ have significantly $\quad(\mathrm{P}<0.05) \quad$ improved soil exchangeable $\mathrm{Ca}^{2+}, \mathrm{Mg}^{2+}$ and $\mathrm{K}^{+}$compared with the control plot in 2002 whereas compost (MOW+Cdj) has significantly decrease exchangeable $\mathrm{Ca}^{2+}$ and $\mathrm{K}^{+}$. In total, the highest soil exchangeable cations improvement was noticed with compost $(\mathrm{MOW}+\mathrm{Cdj}+\mathrm{Csd})$. It has contributed to an increase of $1.2,2.2$ and 1.4 times of exchangeable $\mathrm{Ca}^{2+}, \mathrm{Mg}^{2+}$ and $\mathrm{K}^{+}$respectively compared with the control plot. In the second year experiment (Table 4), exchangeable cations improvement in the soil by the different sources of nutrient was less marked.
Compost $(\mathrm{MOW}+\mathrm{Cdj}+\mathrm{Csd})$ contributed to an increase of 1.5 time of exchangeable $\mathrm{Mg}^{2+}$ compared with the control plot. Results of cation exchange capacity (CEC) follow the same trend with significant $(\mathrm{P}<0.05)$ contribution by compost (MOW+Cdj+Csd) compared with the control plot while compost $(\mathrm{MOW}+\mathrm{Cdj})$ significantly $(\mathrm{P}<0.05)$ decrease by 0.7 time the CEC for both years 2002 and 2003.

The supply of compost $(\mathrm{MOW}+\mathrm{Cdj}+\mathrm{Csd})$ appears to be a suitable source of nutrient for crops in the coastal sandy soil and it has efficiently contributed in the building up of soil organic matter content, important component for soil texture improvement and soil biological activity.

\section{Effect of the different types of compost on cabbage shoot yields \\ Cabbage shoot production as} influenced by the different types of compost during 2002 and 2003 is presented in figure 2. In total during the two years of experiment, the nutrient sources have more or less improved the cabbage shoot biomass. As noticed with soil chemical properties, for both years, compost (MOW+Cdj+Csd) has significantly $(\mathrm{P}<0.05)$ affected the cabbage shoot yield compared with the composts (MOW+Cdj) and (MSR+Cdj) and the control. The highest shoot production was registered with compost (MOW+Cdj+Csd) (6.445 \pm 0.178 t.ha $^{-1}$ and $7.630 \pm 0.173$ t.ha $^{-1}$ during 2002 and 2003 respectively). Based on the fair difference in the yield from one year to an other, the present study recommend compost $(\mathrm{MOW}+\mathrm{Cdj}+\mathrm{Csd})$ to sustain durable crops production in the coastal sandy soil of Benin. Such practice will reduce the dependence in chemical fertilizer.

\section{DISCUSSION}

Compost quality as affected by composting organic materials

The fairly alkaline reaction of the composts is due to the high content of ammonia and cations ( $\mathrm{Ca}, \mathrm{Mg}$ and $\mathrm{K}$ ) within the cottonseeds and chicken dejection added to the organic materials. These results are in accordance with those obtained by Weber et al. (2007), showing that composts at maturity have $\mathrm{pH}$ around 7.3-8.0. The higher 
G. L. AMADJI et al. / Int. J. Biol. Chem. Sci. 3(2): 192-202, 2009

Table 3: Soil chemical properties (mean values \pm standard errors) after harvesting cabbage as influenced by different nutrient sources in 2002.

\begin{tabular}{|c|c|c|c|c|c|c|c|c|c|c|}
\hline Nutrient sources & $\mathrm{pH}_{\mathrm{H} 2 \mathrm{O}}$ & $\mathbf{p H}_{\mathrm{KCl}}$ & $\begin{array}{c}\text { Organic-C } \\
(\%)\end{array}$ & $\begin{array}{c}\text { Total-N } \\
(\%)\end{array}$ & $\begin{array}{c}P_{\text {Bray 1 }} \\
\left(\mathrm{mg} \mathrm{kg}^{-1}\right)\end{array}$ & $\begin{array}{c}\text { Total P } \\
\left(\mathrm{mg} \mathrm{kg}^{-1}\right)\end{array}$ & $\begin{array}{c}\mathrm{Ca} \\
\left(\mathrm{cmol} \mathrm{kg}^{-1}\right)\end{array}$ & $\begin{array}{c}\mathrm{Mg} \\
\left(\mathrm{cmol} \mathrm{kg}^{-1}\right)\end{array}$ & $\begin{array}{c}\mathrm{K} \\
\left(\mathrm{cmol} \mathrm{kg}^{-1}\right)\end{array}$ & $\begin{array}{c}\text { CEC } \\
\left(\mathrm{cmol} \mathrm{kg}^{-1}\right)\end{array}$ \\
\hline Control & $7.20 \pm 0.12 b$ & $7.18 \pm 0.12$ & $0.90 \pm 0.06$ & $0.04 \pm 0.01$ & $57.2 \pm 0.81 \mathrm{c}$ & $166.5 \pm 5.5 \mathrm{~d}$ & $0.61 \pm 0.01 \mathrm{~b}$ & $0.09 \pm 0.00 \mathrm{c}$ & $0.30 \pm 0.01 \mathrm{~b}$ & $1.6 \pm 0.06 \mathrm{~b}$ \\
\hline (MOW+Cdj+Csd) & $7.30 \pm 0.03 \mathrm{ab}$ & $7.28 \pm 0.01$ & $1.02 \pm 0.01$ & $0.05 \pm 0.01$ & $95.2 \pm 0.7 \mathrm{a}$ & $602.7 \pm 4.2 \mathrm{a}$ & $0.73 \pm 0.01 \mathrm{a}$ & $0.19 \pm 0.01 \mathrm{a}$ & $0.42 \pm 0.01 \mathrm{a}$ & $2.4 \pm 0.12 \mathrm{a}$ \\
\hline$(\mathbf{M S R}+\mathbf{C d j})$ & $7.55 \pm 0.08 \mathrm{a}$ & $7.42 \pm 0.01$ & $1.04 \pm 0.02$ & $0.06 \pm 0.01$ & $83.4 \pm 1.5 \mathrm{~b}$ & $450.6 \pm 10 \mathrm{~b}$ & $0.65 \pm 0.03 b$ & $0.13 \pm 0.02 b$ & $0.44 \pm 0.01 \mathrm{a}$ & $1.5 \pm 0.12 b$ \\
\hline CV $(\%)$ & 1.48 & 1.361 & 7.394 & 21.05 & 2.51 & 1.30 & 4.82 & 8.23 & 4.88 & 8.63 \\
\hline
\end{tabular}

Table 4: Soil chemical properties (mean values \pm standard errors) after harvesting cabbage as influenced by different nutrient sources in 2003.

\begin{tabular}{|c|c|c|c|c|c|c|c|c|c|c|}
\hline Nutrient sources & $\mathrm{pH}_{\mathrm{H} 2 \mathrm{O}}$ & $\mathbf{p H}_{\mathrm{KCl}}$ & $\begin{array}{c}\text { Organic-C } \\
(\%)\end{array}$ & $\begin{array}{c}\text { Total-N } \\
(\%)\end{array}$ & $\begin{array}{c}P_{\text {Bray 1 }} \\
\left(\mathrm{mg} \mathrm{kg}^{-1}\right)\end{array}$ & $\begin{array}{c}\text { Total P } \\
\left(\mathrm{mg} \mathrm{kg}^{-1}\right)\end{array}$ & $\begin{array}{c}\mathrm{Ca} \\
\left(\mathrm{cmol} \mathrm{kg}^{-1}\right)\end{array}$ & $\begin{array}{c}\mathrm{Mg} \\
\left(\mathrm{cmol} \mathrm{kg}^{-1}\right)\end{array}$ & $\begin{array}{c}\mathrm{K} \\
\left(\mathrm{cmol} \mathrm{kg}^{-1}\right)\end{array}$ & $\begin{array}{c}\text { CEC } \\
\left(\mathrm{cmol} \mathrm{kg}^{-1}\right)\end{array}$ \\
\hline Control & $7.46 \pm 0.01 \mathrm{~b}$ & $7.38 \pm 0.02$ & $0.94 \pm 0.01 \mathrm{~b}$ & $0.04 \pm 0.01$ & $58 \pm 3.5 \mathrm{c}$ & $172.5 \pm 1.4 \mathrm{~d}$ & $0.65 \pm 0.03 \mathrm{a}$ & $0.11 \pm 0.00 \mathrm{c}$ & $0.34 \pm 0.02 \mathrm{ab}$ & $1.2 \pm 0.12 \mathrm{a}$ \\
\hline (MOW+Cdj) & $7.51 \pm 0.02 \mathrm{~b}$ & $7.46 \pm 0.02$ & $1.1 \pm 0.06 \mathrm{a}$ & $0.06 \pm 0.01$ & $83 \pm 1.8 \mathrm{~b}$ & $238.9 \pm 1.2 \mathrm{c}$ & $0.54 \pm 0.03 \mathrm{~b}$ & $0.13 \pm 0.00 \mathrm{~b}$ & $0.27 \pm 0.02 \mathrm{~b}$ & $0.8 \pm 0.12 \mathrm{~b}$ \\
\hline$(\mathrm{MOW}+\mathrm{Cdj}+\mathrm{Csd})$ & $7.42 \pm 0.02 \mathrm{~b}$ & $7.36 \pm 0.04$ & $1.2 \pm 0.03 \mathrm{a}$ & $0.05 \pm 0.01$ & $99.2 \pm 2.3 \mathrm{a}$ & $606.7 \pm 3.8 \mathrm{a}$ & $0.69 \pm 0.02 \mathrm{a}$ & $0.17 \pm 0.00 \mathrm{a}$ & $0.40 \pm 0.04 \mathrm{a}$ & $1.6 \pm 0.06 \mathrm{a}$ \\
\hline$(\mathbf{M S R}+\mathrm{Cdj})$ & $7.75 \pm 0.03 \mathrm{a}$ & $7.46 \pm 0.04$ & $1.1 \pm 0.06 \mathrm{a}$ & $0.06 \pm 0.01$ & $81.4 \pm 0.8 \mathrm{~b}$ & $448.6 \pm 2.3 \mathrm{~b}$ & $0.69 \pm 0.03 \mathrm{a}$ & $0.11 \pm 0.00 \mathrm{c}$ & $0.42 \pm 0.01 \mathrm{a}$ & $1.3 \pm 0.12 \mathrm{a}$ \\
\hline CV $(\%)$ & 0.535 & 0.813 & 5.262 & 19.048 & 5.632 & 1.272 & 8.696 & 4.042 & 12.793 & 15.453 \\
\hline
\end{tabular}

$(\mathrm{MSR}+\mathrm{Cdj})=$ Maize stover residues mixed with Chicken dejection. Means within each column followed by the same letter are not significantly different $(P>0.05)$ according to

Student Newman-Keuls test. 


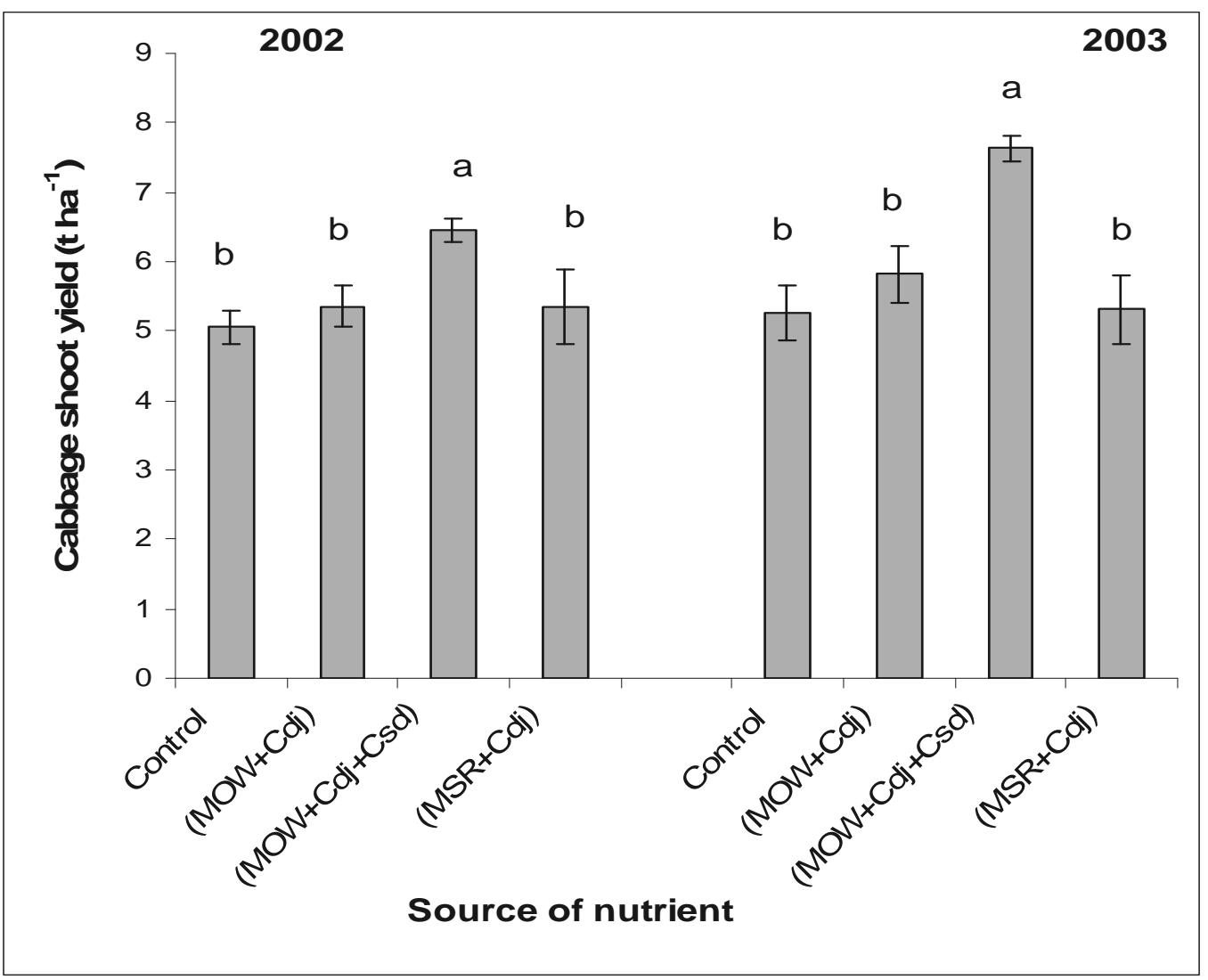

Figure 2: Cabbage shoot yield in sandy soil as influenced by different nutrient sources during 2002 and 2003. Vertical bars denote standard errors. Bars of the same types labelled with the same letter are not significantly different at $\mathrm{P}>0.05$ (Student Newman-Keuls test). Note: $(\mathrm{MOW}+\mathrm{Cdj})=$ Municipal organic wastes mixed with chicken dejection ; $(\mathrm{MOW}+\mathrm{Cdj}+\mathrm{Csd})=$ Municipal organic wastes mixed with chicken dejection and cottonseeds $;(\mathrm{MSR}+\mathrm{Cdj})=$ Maize stover residues mixed with Chicken dejection.

potassium and nitrogen contents in the compost $(\mathrm{MOW}+\mathrm{Cdj}+\mathrm{Csd})$ comparatively to the composts $(\mathrm{MOW}+\mathrm{Cdj})$ and $(\mathrm{MSR}+$ Cdj) could be attributed to an input from the cottonseeds which is known to contain high $\mathrm{N}$ and $\mathrm{K}$ concentration (12.5-16.82 $\mathrm{g} / \mathrm{kg}$ and $12.4-15.8 \mathrm{~g} / \mathrm{kg}$ of $\mathrm{N}$ and $\mathrm{K}$ respectively; Acakpo, 2004). In fact, the compost (MOW+Cdj+Csd) contains half quantity of organic waste and more $\mathrm{N}$-rich materials compared with composts $(\mathrm{MOW}+\mathrm{Cdj})$ and (MSR+Cdj) leading to high $\mathrm{N}$ concentration.

The average $\mathrm{C}: \mathrm{N}$ ratios of 10 to 12 of the composts are quite favourable for soil microbiological processes (Swift and Woomer, 1993; Busby et al., 2007), especially the infertile coastal sandy soil as they do not create nitrogen hunger for the plants (Juste and Pommel, 1987; Chaves et al., 2007; Tognetti et al., 2008) and it is a good indicator to nitrogen mineralization (Sikora and Szmidt, 2001; Kowaljow and Mazzarino, 2007). Such characteristic of the studied composts would have positive effect on the fertility status of the coastal sandy soil by releasing nutrient for the growing plant.

In summary, from the different parameters studied, compost $(\mathrm{MOW}+\mathrm{Cdj}+$ Csd) enriched with chicken and cottonseeds, presents good characteristics therefore, could be recommended to the gardeners for the restoration of the infertile sandy soil.

\section{Efficacy of the composts on soil fertility improvement}

It is commonly known that compost application improves soil properties, which is connected with an increase in the organic 
carbon content (Busby et al., 2007; Tognetti et al., 2008). As expected on the basis of the compost properties, compost $(\mathrm{MOW}+\mathrm{Cdj}+$ Csd) shows the highest soil organic $\mathrm{C}$ and nutrient concentration, followed by compost $(\mathrm{MSR}+\mathrm{Cdj})$ as a consequence of input of the N-rich materials (cottonseeds and chicken dejection) to the organic waste. These results are in accordance with those obtained by Celik et al. (2004), Busby et al. (2007) and Weber et al. (2007) on sandy soil. This was attributable to differences in the quality of compost organic matter. Results imply that, the efficacy of organic waste compost in soil fertility improvement is much more related to the quality of the organic residue added to improve its quality. The results of the present experiment show that, chicken dejection alone as shown with result of compost (MOW + Cdj) is not sufficient to improve significantly the fertility of the sandy soils.

\section{Efficacy of the composts on crop yield improvement}

An increase of $24.4 \%$ of the cabbage shoot yield comparatively to the control was noticed with compost (MOW + Cdj + Csd) while the remaining composts show yields almost similar with the control plot. This yield improvement was obviously attributed to nutrient supply from the compost (MOW + $\mathrm{Cdj}+\mathrm{Csd})$ at the later growth stages of the cabbage. Such positive effect of compost on cabbage yield improvement was also mentioned by Amadji (2001) using organic municipal compost on ferruginuous soils. The author found yield increase of $300 \%$ compared with the unfertilized control plot. This gap between the two yields could be explained by the high inherent fertility level the finest texture of the ferruginous compared with the coastal sandy soil studied.

The non significant differences between cabbage yields with composts $(\mathrm{MOW}+\mathrm{Cdj})$ and $(\mathrm{MSR}+\mathrm{Cdj})$ and that of the control was attributable to their low nutrient concentration and their poor physical quality compared with compost (MOW + Cdj + Csd). These results imply that, in terms of the management of the fertility of sandy soil, it is suggested to increase the dose of these composts in order to provide after the mineralization process, sufficient nutrient input to the plant at the later growth stage.
Furthermore, as shown by Chaves et al. (2007), an additional beneficial effect would be achieved if the synchronization between nutrient release and crop nutrient demand, this mostly lead to an increase in the nutrient use efficiency.

\section{Conclusion}

The present study indicated that application of municipal solid waste composts enriched with N-rich material to sandy soils has positive effects on the fertility levels, therefore crop yield. However, the magnitude of beneficial changes depends on the quality and quantity of organic material added to the municipal solid waste. The mixture of municipal solid wastes with chicken manure and cottonseeds (MOW + $\mathrm{Cdj}+\mathrm{Csd}$ ) has improved significantly the quality of the compost, therefore soil organic matter and nutrient concentration. As consequence, it has highly improved the yield of cabbage shoot on the coastal sandy soil. Hence, recycling municipal organic waste in compost with cottonseeds and chicken dejection for vegetable production in sandy coastal soil is a potentially powerful, locally responsive approach to addressing both waste disposal problems and marginal soil fertility restoration.

\section{ACKNOWLEDGEMENTS}

The constructive comments on an earlier version of the manuscript by two anonymous reviewers are gratefully acknowledged.

\section{REFERENCES}

Acakpo CC. 2004. Efficacité agronomique et rationalité paysanne autour de la gestion des fumures minérales et de leurs effets résiduels dans les systèmes de production coton-maïs au centre Bénin. Ingénieur Agronome, Thesis. FSA/UAC, Abomey-Calavi, Bénin, p. 91.

Amadji G. 2001. Utilisation du compost sous l'arachide sur un sol ferrugineux tropical dégradé. In Recherche Agricole pour le Développement, Agbo BP, Arodokoun DY, Aïhou K, Matthess A (eds). Proceeding of the atelier scientifique, 11-12 january. INRAB: Bénin; 144-151.

Assogba KF. 2001. Valorisation des déchets organiques de la ville pour la production 
de légumes dans les sols sableux du littoral: cas du site maraîcher de l'ONEPI. In Recherche Agricole Pour le Développement, Agbo BP, Arodokoun DY, Aïhou K, Matthess A (eds). Proceeding of the atelier scientifique, 11-12 january. INRAB: Bénin; 144-151.

Brock B. 1999. Actual and potential contribution of urban agriculture to environmental sanitation: a case study in Cotonou. In Urban Agriculture in West Africa: Contributing to Food Security and Urban Sanitation, Olanrewaju BS (ed). International Development. Research Centre, Ottawa Canada/ Technical Centre for Agricultural and Rural Cooperation: Wageningen, The Netherlands; 126-137.

Busby RH, Torbert A, Gebhart DL. 2007. Carbon and nitrogen mineralization of non-composted and composted municipal solid waste in sandy soils. Soil Biol. Bioch., 39: 1277-1283.

Celik I, Ortas I, Kilic S. 2004. Effects of composts, mycorrhiza, manure and fertilizer on some physical properties of chromoxerert soil. Soil \& Tillage Res., 78: $59-67$.

Chaves B, De Veve S, Boeckx P, Van Cleemput O, Hofman G. 2005. Screening organic biological waste materials for their potential to manipulate the $\mathrm{N}$ release of $\mathrm{N}$-rich crop residues in soil. Agric. Ecos. Env., 111: 81-92.

Chaves B, De Neve S, Piulats LM, Boeckx P, Van Cleemput O, Hofman G. 2007. Manipulation the $\mathrm{N}$ release from $\mathrm{N}$-rich crop residues by using organic wastes on soils with different textures. Soil Use and Man., 23: 212-219.

Crichton L, Shrama A, Hewett SS, Ortega LB. 2000. Report of Resource Recovery Forum 2000. Recycling Achievements in Europe. Ellesemere Press: Skipon North, Yorkshire; 44.

Dabin B. 1967. Application des dosages automatiques à l'analyse des sols. $3^{\mathrm{e}}$ partie, Cahier ORSTOM, série Pédologie, 3: 257-286.

De Neve S, Gaona Sae'z S, Chaves Daguilar B, Sleutel S, Hofman G. 2004. Manipulating $\mathrm{N}$ mineralization from high $\mathrm{N}$ crop residues using on- and off- farm organic materials. Soil Biol. Bioch., 36: 127-134.

Douglas JT, Aitken MN, Smith CA. 2003. Effects of five non-agricultural organic wastes on soil composition, and on the yield and nitrogen recovery on Italian ryegrass. Soil Use Man., 19: 135-138.

Drozd J. 2003. The risk and benefits associated with utilizing composts from municipal solid waste (MSW) in agriculture. In Innovative Soil-Plant Systems for Sustainable Agricultural Practices, Lynch JM, Schepers JS, Unver I (eds). OECD: Paris; 211-226.

Illera V, Walter I, Souza P, Cala V. 2000. Short-term effects of biosolid and municipal solid waste applications on heavy metals distribution in a degraded soils under a semi-arid environment. Sci. Total Env., 255: 29-44.

Juste C, Pommel B. 1987. La Valorisation Agricole des Déchets: le Compost Urbain. Ministère de la culture et de l'Environnement : Paris, France; 9-17.

Kowaljow E, Mazzarino MJ. 2007. Soil restauration in semiarid Patagonia: chemical and biological response to different compost quality. Soil Biol. Bioch., 39: 1580-1588.

Laos F, Satti P, Walter I, Mazzarino MJ, Moyano S. 2000. Nutrient availability of composted and noncomposted residues in a Patagonia Xeric Mollisol. Biol. Fert. Soils, 31: 462-469.

Mallouhi N, Bioyara JP. 1997. Effet de Leucaena leucocephala, des fientes de volaille ou du fumier de bovins sur la productivité du maïs cultivé sur "terre de barre" au sud Bénin. Tropicultura, 15(2): 67-70.

McBride MB. 2003. Toxic metals in sewage sludge-amended soils: has promotion of beneficial use discounted the risks? Advances Env. Res., 8: 5-19.

Nissen TM, Wander MW. 2003. Management and soil-quality effects on fertilizer-use efficiency and leaching. Soil Sci. Soc. Am. J., 67: 1524-1532.

Page AL, Miller RH, Keeney DR. 1982. Methods of soil analysis, part 2, $\left(2^{\text {nd }}\right.$ edn), Soil Sci. Soc. Am. Madison, USA.

Sikora LJ, Szmidt AK. 2001. Nitrogen sources, mineralization rates, and nitrogen nutrition benefits to plants from 
composts. In Compost Utilization in Horticultural Cropping Systems, Stoffella PJ, Kahn BA (eds). Lewis Publishers: New York, USA; 287-305.

Swift MJ, Woomer P. 1993. Organic matter and the sustainability of agricultural systems: Definition and measurement. In Soil Organic Matter Dynamics and Sustainability of Tropical Agriculture. Mulongoy K, Merckx R (eds). Leuven, (Belgium): IITA/ K.U. Leuven; 3-18.

Tognetti C, Mazzarino MJ, Laos F. 2008. Compost of municipal organic waste: effects of different management practices on degradability and nutrient release capacity. Soil Biol. Bioch., 49: 2290-2296.

Walkley A, Black JA. 1934. An examination of the Detjareff method for determining soil organic matter and a proposed modification of the chromatic acid titration method. Soil Sci., 37: 29-38.

Weber J, Karczewska A, Drozd J, Licznar M, Licznar S, Jamroz E, Kocowicz A. 2007. Agricultural and ecological aspects of a sandy soil as affected by the application of municipal solid waste composts. Soil Biol. Bioch., 39: 1294-1302. 